\title{
PENGARUH KEPERCAYAAN, KEMUDAHAN DAN KUALITAS INFORMASI TERHADAP KEPUTUSAN PEMBELIAN SECARA ONLINE DI APLIKASI SHOPEE
}

\author{
Subagyo*), Tukidi \& Indah WV \\ *)Dosen Tetap Program S1 Jurusan Manajemen Fakultas Ekonomi Universitas Satya Negara Indonesia \\ E-mail: bagyolink@.cbn.net.id, tukidi1965@yahoo.com, indahwv@gmail.com
}

\begin{abstract}
This research aims to determine the impact of trust, easiness, and quality information on purchasing decisions online in the Shopee app. The method used in this research is the quantitative method and assessment of the results based on respondents 'answers using a Likert scale. The population in this study is all consumers of Satya Negara Indonesia University student $A$ and the samples in this study amounted to 100, and the sampling Tekhnik used in this study was Probability Sampling, and Sample determination based on simple random sampling. The data analysis methods used in the study are test instruments (validity and reusability), Data normality analysis, assumption Test (normality, multicholinerity, heterokedastisity, autocorrelation), correlation coefficient test, linear regression test Multiple, F-Test, T-Test, and coefficient of determinant $\left(R^{2}\right)$. The results showed that simultaneously (test $F$ ) showed that there was a significant influence between the trust variables (X1), the easiness (X2), and the quality of information (X3) against the purchase decision (Y). Partial (T-Test) the trust is influential as positive to the purchase decision, whereas the easiness variable does not affect as positive to the purchase decision, and the information quality has effect as negative to Purchase decision.
\end{abstract}

Keywords: trust, easiness, quality of information and purchasing decisions

\begin{abstract}
ABSTRAK
Penelitian ini bertujuan untuk mengetahui Pengaruh Kepercayan, Kemudahan, dan Kualitas Informasi Terhadap Keputusan Pembelian secara online di Aplikasi Shopee. Metode yang di gunakan pada penelitian ini adalah metode kuantitatif dan penilaian dari hasil penelitian ini berdasarkan jawaban responden dengan menggunakan skala likert. Populasi dalam penelitian ini adalah seluruh konsumen Mahasiswa Universitas Satya Negara Indonesia kampus A dan sampel dalam penelitian ini berjumlah 100, dan Teknik pengambilan sampel yang di gunakan dalam penelitian ini adalah Probability Sampling, dan penentuan sampel berdasarkan simple random sampling. Metode analisa data yang digunakan dalam penelitian adalah Uji Instrumen (Validitas dan Reabilitas), Analisis Normalitas Data, Uji Asumsi (Normalitas, Multikolinieritas, Heterokedastisitas, Autokorelasi), Uji Koefisien korelasi, Uji Regresi linier berganda ,Uji F, Uji t, Dan Koefisien Determinan $\left(\mathrm{R}^{2}\right)$. Hasil penelitian menunjukkan bahwa secara simultan (uji F) menunjukkan bahwa terdapat pengaruh yang signifikan antara variabel Kepercayaan $\left(\mathrm{X}_{1}\right)$,Kemudahan $\left(\mathrm{X}_{2}\right)$, dan Kualitas Informasi $\left(\mathrm{X}_{3}\right)$ terhadap Keputusan Pembelian (Y). Secara parsial (uji t) Kepercayaan berpengaruh positif terhadap keputusan Pembelian, sedangkan variabel Kemudahan tidak berpengaruh positif terhadap Keputusan Pembelian dan Kualitas Informasi berpengaruh negatif terhadap Keputusan Pembelian.
\end{abstract}

Kata Kunci : Kepercayaan, Kemudahan, Kualitas Informasi dan Keputusan Pembelian

\section{PENDAHULUAN}

Perkembangan teknologi digital saat ini sangat amat pesat yang menyebabkan perubahan kultur budaya dan kebiasaan kita sehari-hari. Menurut HootSuite (2019) pengguna internet di seluruh dunia mencapai 4.388 miliar orang. Sementara itu di Indonesia pengguna 
internet telah mencapai 132 juta orang, atau 50\% dari jumlah penduduk Indonesia yang 268 jt penduduk. $73 \%$ dari masyarakat Indonesia mengakses internet dengan menggunakan ponsel pintarnya. HootSuite juga mengatakan dalam menggunakan internet membutuhkan rata-rata enam jam per hari melalui berbagai macam media. Sementara itu di Indonesia dalam hal waktu penggunaan internet menempati peringkat keempat dunia dengan durasi rata-rata menggunakan internet selama 8 jam 36 menit setiap harinya.

Teknologi E-commerce mengubah pola perilaku masyarakat dalam membeli suatu produk. Masyarakat cenderung lebih memilih suatu yang cenderung bersifat mudah dan praktis. Pola perilaku masyarakat tersebut pula yang dapat mengeser gaya konsumsi masyarakat yang tadinya toko konvensional (offline) menjadi toko daring/ online .

Perubahan gaya hidup dan perilaku konsumen pada saat ini juga mengubah pola pembelian yang terjadi pada mahasiswa. Saat ini mahasiswa mulai beralih dan menjadikan pilihan belanja online yang lebih mudah. Shopee mulai berkembang dan memberikan kemudahan pada Mahasiswa yang sebagian besar telah memanfaatkan kecanggihan teknologi. Hal ini juga ditemukan oleh penulis saat melakukan pra penelitian di Kampus Universitas Satya Negara Indonesia Kampus A yang memiliki populasi 2.695 Mahasiswa. Berdasarkan pra penelitian yang dilakukan oleh penulis pada mahasiswa Universitas Satya Negara Indonesia kampus A menemukan fakta bahwa dari 25 mahasiswa Universitas Satya Negara Indonesia ternyata, 19 mahasiswa lebih tersebut menyukai berbelanja online dan 6 mahasiswa tersebut tidak menyukai berbelanja online. Mereka yang menyukai belanja online 13 mahasiawa berjenis kelamin wanita. Sementara itu mahasiswa yang menyukai berbelanja online mereka yang menyukai berbelanja melalui e-commerce Lazada sebanyak 10 mahasiswa, sementara itu di peringkat dua mahasiswa yang memilih shopee sebanyak 6 mahasiswa, dan yang memilih Tokopedia sebanyak 3 mahasiswa.

Aktifitas jual beli secara online biasa kita sebut dengan e-commerce dengan model market place merupakan sesuatu yang saat ini sedang banyak digemari oleh pengguna internet, termasuk mahasisiwa. Market place itu sendiri merupakan sebuah perantara penghubung yang digunakan oleh para penjual dan pembeli yang dapat melindungi pembeli dari berbagai macam penipuan oleh para penjual. Dari observasi yang dilakukan peneliti lakukan dalam persaingan bisnis online di Indonesia terdapat aplikasi yang populer di masyarakat sebagaimana dalam (Iprice insight, 2018) di bawah ini :

\section{Tabel 1}

Data visitor E-commerce

\begin{tabular}{|c|c|c|}
\hline \multicolumn{3}{|c|}{$\mathbf{2 0 1 8}$} \\
\hline NO & Aplikasi & Jumlah Visitor \\
\hline 1 & TOKOPEDIA & 444.853 .500 \\
\hline 2 & BUKALAPAK & 286.260 .900 \\
\hline 3 & LAZADA & 262.256 .400 \\
\hline 4 & SHOPEE & 171.914 .100 \\
\hline 5 & BLIBLI & 144.384 .900 \\
\hline 6 & JD.ID & 52.860 .400 \\
\hline
\end{tabular}

Sumber: iprice insights (2018)

Dari table data di atas merupakan fenomena tekhnologi masa kini dimana trdapat shifting perilaku konsumen dalam berbelanja. Shopee merupakan perusahaan e-commerce dengan model market place yang menawarkan pengalaman seperti belanja dengan cepat dan mudah yang menawarkan berbagai produk beberapa kategori seperti makanan, peralatan rumah tangga, perlengkapan kerja, peralatan traveling, peralatan kecantikan, buku, dan lain sebagainya. Berikut merupakan data penggunjung Shopee di Indonesia. 
Tabel. 2

Data Kunjungan Konsumen Shopee

\begin{tabular}{|c|c|c|c|c|}
\hline No. & Data Per Kuartal & $\begin{array}{c}\text { Visitor Per } \\
\text { Bulan }\end{array}$ & $\begin{array}{c}\text { App Store } \\
\text { Rank }\end{array}$ & $\begin{array}{c}\text { Play Store } \\
\text { Rank }\end{array}$ \\
\hline 1. & Jan - Mar 2018 & $34,5 \mathrm{jt}$ & $\# 1$ & $\# 1$ \\
\hline 2. & Apr - Juni 2018 & $30,8 \mathrm{jt}$ & $\# 1$ & $\# 1$ \\
\hline 3. & Juli - Sept 2018 & $38,8 \mathrm{jt}$ & $\# 1$ & $\# 1$ \\
\hline 4. & Okt - Des 2018 & $67,6 \mathrm{jt}$ & $\# 1$ & $\# 1$ \\
\hline
\end{tabular}

Sumber : iprice insight (2018)

Dari data diatas dapat dinyatakan bahwa pengunjung Shopee di tahun 2018 setiap 3 bulannya mengalami peningkatan kecuali pada kuartal 2. Disamping itu dalam hal peringkat e-commerce App Store dan Play Store shopee menempati peringkat 1 semenjak kuartal pertama pada tahun 2018. Hal ini dapat disebabkan oleh beberapa faktor yang mempengaruhinya seperti atas kepercayaan dari e-commerce tersebut, Kemudahan penggunaan aplikasi tersebut, dan dikarnakan kualitas informasi yang tersedia di e-commerce Shopee. Menurut Desi Wahyuni dan Endang Prihatini (2018:9) dalam jurnalnya menyatakan adanya hubungan antara keputusan pembelian dengan kemudahan, kualitas informasi, dan kepercayaan

Berdasarkan latar belakang penelitian yang telah dikemukakan diatas, maka peneliti tertarik melakukan penelitian dengan judul "Pengaruh Kepercayaan, Kemudahan dan Kualitas Informasi Terhadap Keputusan Pembelian Secara Online Di Aplikasi Shopee (Studi Kasus Pada Mahasiswa Universitas Satya Negara Indonesia Kampus A)”.

\section{Tujuan Penelitian}

a. Untuk mengetahui pengaruh Kepercayaan, Kemudahan, dan Kualitas Informasi terhadap Keputusan Pembelian Online di Shopee

b. Untuk mengetahui pengaruh Kepercayaan terhadap Keputusan Pembelian Online di Shopee

c. Untuk mengetahui Pengaruh Kemudahaan terhadap Keputusana Pembelian Online di Shopee

d. Untuk mengetahui pengaruh Kualitas Informasi terhadap Keputusan Pembelian Online di Shopee

\section{TINJAUAN PUSTAKA}

\section{Kepercayaan}

Menurut Kotler dan Keller (2012:219) kepercayaan merupakan kesediaan dari perusahaan untuk mengandalkan para mitra bisnis. Semua itu tergantung dari sejumlah faktor interpersonal dan antar organisasi, seperti kompetensi perusahaan, integritas, kejujuran, dan perbuatan baik.Pengertian kepercayaan adalah gagasan deskriptif yang dimiliki seseorang tentang objek, atribut dan manfaatnya.

\section{Kemudahan}

Menurut Jogiyanto (2007:115) Kemudahan penggunaan di definisikan sebagai sejauh mana seseorang percaya terhadap penggunaan teknologi informasi tersebut sehingga mudah untuk digunakan. Jika seseorang percaya terhadap teknologi yang digunakan maka dia akan menggunakannya sehingga kemudahan ini juga merupakan kepercayaan tentang proses pengambilan keputusan. 
Pengertian Kemudahan adalah seberapa besar seseorang percaya suatu teknologi dapat dengan mudah dipergunakan dan juga bebas dari segala usaha.

\section{Kualitas Informasi}

Menurut Mukhtar Luthfiya (2014:33) Informasi yang disajikan pada online shop sebaiknya mencakup informasi berkaitan dengan produk dan jasa yang ada pada online shop .informasi tersebut sebaianya berguna dan relevan dalam memprediksi kualitas dan kegunaan produk atau jasa.

Pengertian Kualitas Informasi adalah segala sesuatu presepsi dari konsumen tehadap informasi apa yang mereka dapatkan berdasarkan nilai kemanfaatan yang disediakan oleh sebuah website.

\section{Keputusan Pembelian}

Menurut Tjiptono (2014:21) Keputusan pembelian adalah proses dimana konsumi informasi mengenai produk atau merek tertentu untuk menvaluasi seberapa baik masingmasing alternatif tersebut dapat memecahkan masalahn yang kemudian mengaruh kepada keputusan pembelian.

Suhari (2008:143) keputusan pembelian online yakni proses seorang konsumen ketika menggunakan media internet untuk melakukan pembelian sebuah produk atau jasa dimulai dengan timbulnya awareness (kesadaran) konsumen akan suatu informasi atau produk yang dapat diperoleh dari internet.

\section{Penelitian Terdahulu}

Maria dan Helen (2015) penelitian yang berjudul "Analisa Pengaruh Kepercayaan, Kemudahan, Kualitas Informasi, Dan Tampilan Produk Terhadap Keputusan Pembelian Melalui Pemasaran Di Media Sosial. Studi pada penguna media sosial di shapeharve."menyatakan bahwa hasil penelitian variabel Kepercayaan berpengaruh signifikan terhadap keputusan pembelian .

Resti Hidayah (2018) penelitian yang berjudul "Pengaruh Kepercayaan, Kemudahan, Dan Keamanan Terhadap Keputusan Pembelian Pada Situs E-Marketplace." menyatakan bahwa hasil penelitian variabel Kemudahan tidak memiliki pengaruh signifikan terhadap keputusan pembelian.

Riski Armanti (2015) penelitian yang berjudul "Pengaruh Kepercayaan, Kemudahan, Kualitas Informasi Dan Persepsi Resiko Terhadap Keputusan Pembelian Melalui Situs Jejaring Sosial Di Semarang" menyatakan bahwa hasil penelitian variabel Kualitas Informasi berpengaruh secara signifikan Terhadap keputusan pembelian.

\section{Kerangka Pemikiran}

H1

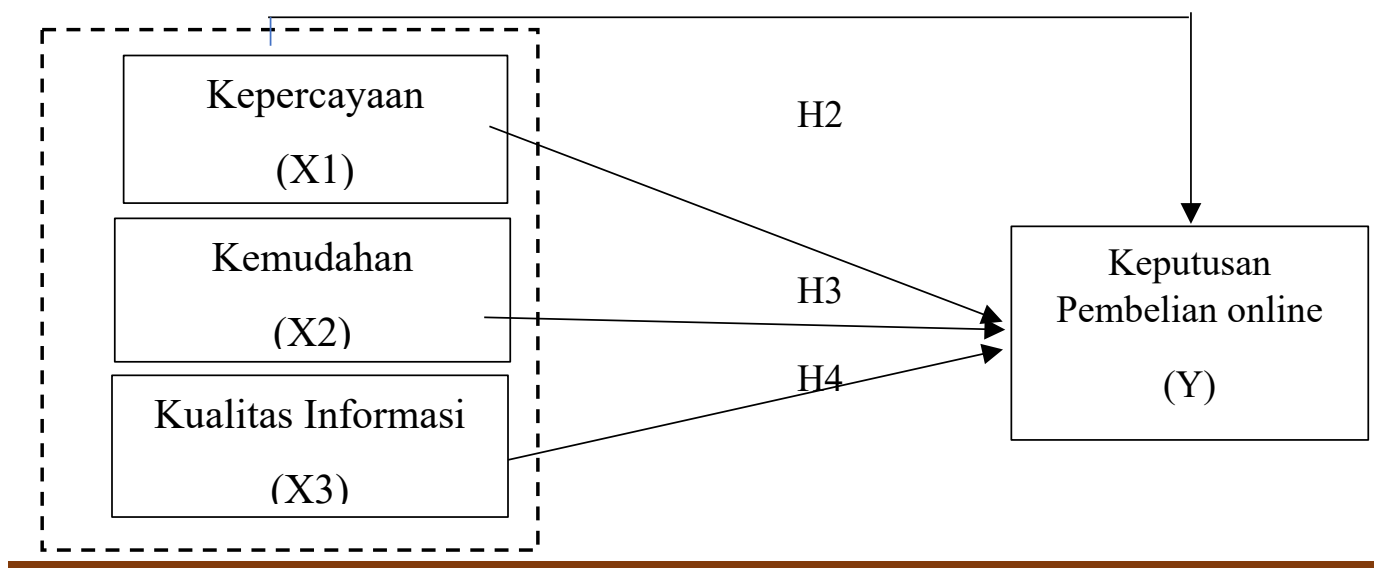

Jurnal Manajemen Universitas Satya Negara Indonesia - Vol 4 No 1 - Agustus 2019 


\section{Hipotesis Penelitian}

$\mathrm{H}_{1}$ : Kepercayaan, Kemudahan, dan Kualitas Informasi berpengaruh terhadap Keputusan Pembelian online di aplikasi Shopee.

$\mathrm{H}_{2}$ : Kepercayaan berpengaruh terhadap Keputusan Pembelian online di aplikasi Shopee.

$\mathrm{H}_{3}$ : Kemudahan berpengaruh terhadap Keputusan Pembelian online di aplikasi Shopee.

$\mathrm{H}_{4}$ : Kualitas Informasi berpengaruh terhadap Keputusan Pembelian online di aplikasi Shopee.

\section{METODE PENELITIAN}

\section{Waktu dan Tempat Penelitian}

Penelitian ini dilakukan di Universitas Satya Negara Indonesia Kampus A. Penelitian dilakukan mulai dari bulan April 2019 s/d Juli 2019.

\section{Desain Penelitian}

Jenis penelitian ini adalah penelitian kausal yaitu penelitian untuk mengetahui pengaruh satu atau lebih variabel bebas (independent variable) terhadap variabel terikat (dependent variable)

\section{Jenis Data}

Pada penelitian jenis data menggunakan data primer (seperti hasil wawancara atau hasil pengisian kuesioner) dan data sekunder (studi kepustakaan, jurnal-jurnal penelitian yang berhubungan dan mendukung penelitian, internet, dan media).

\section{Metode Pengumpulan Data}

Teknik pengumpulan data yang dipergunakan dalam penelitian ini adalah sebagai berikut:
a. Studi Kepustakaan
b. Metode Kuisioner
c. Observasi

\section{Populasi dan Sampel}

Populasi ini dilakukan pada seluruh Mahasiswa Universitas Satya Negara Indonesia Kampus A yang menggunakan aplikasi Shopee tahun akademik 2018/2019. Dalam penelitian ini menggunakan rumus Solvin dengan penetapan sampel yang digunakan yaitu:

$$
\mathrm{n}=\frac{N}{1+N e^{2}}
$$

$$
\mathrm{n}=\frac{2.695}{1+2.695(0,1)^{2}}=96,42
$$

Dalam penelitian kali ini penulis mengambil taraf kesalahan sebesar 10\%

Keterangan :

$$
\begin{aligned}
& \mathrm{n}=\text { Ukuran Sampel } \\
& \mathrm{N}=\text { Ukuran Populasi } \\
& \mathrm{e}=\text { Taraf kesalahan }
\end{aligned}
$$

Tekhnik Penarikan sampel

Dari hasil perhitungan tersebut peneliti mnggunakan sampel sebanyak 100 responden. 


\section{ANALISIS HASIL DAN PEMBAHASAN}

\section{Uji Validitas}

Uji Validitas bertujuan untuk mengetahui seberapa cermat suatu item dalam mengukur apa yang ingin diukur (kuisioner)(Priyatno, 2017:63).Hasil yang didapat penulis merupan seluruh pernyataan valid sesuai dengan hasil SPSS penulis yang mana $r$ hitung $>r$ tabel

\section{Uji Reliabilitas}

Menurut Priyatno (2017:79) Uji reliabilitas digunakan untuk mengetahui keajegan atau konsistensi alat ukur yang biasanya menggunakan kuesioner. Hasil yang didapat penulis merupan seluruh pernyataan Reliabel sesuai dengan hasil SPSS dengan nilai Cronbach Alpha $>0,6$ yang berarti reliabel.

\section{Uji Deskriptif}

Analisis deskriptif digunakan untuk menggambarkan tentang statistik data seperti min, max, mean, sum, standard deviasi, variance, range, dan lain-lain, untuk mengukur distribusi data dengan skewness dan kurtosis.

Tabel 1. Descriptive Statistics

\begin{tabular}{|l|c|r|r|r|r|}
\hline & $\mathrm{N}$ & $\begin{array}{c}\text { Minimu } \\
\mathrm{m}\end{array}$ & $\begin{array}{c}\text { Maximu } \\
\mathrm{m}\end{array}$ & Mean & $\begin{array}{c}\text { Std. } \\
\text { Deviation }\end{array}$ \\
\hline Kepercayaan & 100 & 33 & 58 & 45,80 & 4,667 \\
Kemudahan & 100 & 15 & 30 & 24,04 & 3,123 \\
Kualitas Informasi & 100 & 23 & 40 & 31,26 & 3,675 \\
Keputusan Pembelian & 100 & 31 & 51 & 42,44 & 4,115 \\
Valid N (listwise) & 100 & & & & \\
\hline
\end{tabular}

Sumber : Diolah oleh penulis melalui SPSS 22 (2019)

\section{Uji Asumsi Klasik}

Uji Asumsi Klasik dilakukan untuk memastikan persamaan linear regresi berganda memenuhi persyaratan normalitas, tidak terjadi heteroskedastitas, tidak terjadi multikolinearitas.

\section{Uji Normalitas}

Menurut Priyatno (2017:109) Uji Normalitas untuk mengetahui apakah data berdistribusi normal atau tidak. Uji normalitas dalam penelitian ini mengunakan metode Kolmogorov Smirnov.

Tabel 2. Tests of Normality

\begin{tabular}{|l|r|c|r|r|r|r|}
\hline & \multicolumn{2}{|c|}{ Kolmogorov-Smirnov } & \multicolumn{3}{|c|}{ Shapiro-Wilk } \\
\cline { 2 - 7 } & $\begin{array}{c}\text { Statisti } \\
\mathrm{c}\end{array}$ & \multicolumn{1}{c|}{ df } & \multicolumn{1}{c|}{ Sig. } & Statistic & df & \multicolumn{1}{c|}{ Sig. } \\
\hline Kepercayaan &, 083 & 100 &, 087 &, 987 & 100 &, 437 \\
Kemudahan &, 079 & 100 &, 123 &, 980 & 100 &, 143 \\
Kualitas Informasi &, 080 & 100 &, 113 &, 983 & 100 &, 222 \\
Keputusan Pembelian &, 067 & 100 &, $200^{*}$ &, 987 & 100 &, 435 \\
\hline
\end{tabular}

Sumber : Diolah oleh penulis melalui SPSS 22 (2019)

Dapat disimpulkan Kepercayaan(X1), Kemudahaan (X2), Kualitas informasi (X3) dan Keputusan Pembelian (Y) mempunyai nilai nilai Kolmogrof - smirnov > 0,05 maka menunjukkan data distribusi normal. 


\section{Uji Multikolinieritas}

Menurut Priyatno (2017:120), Multikolinieritas artinya antara variabel independen yang terdapat dalam model regresi memiliki hubungan linear yang sempurna atau mendekati sempurna (koefisien korelasinya tinggi atau bahkan 1).

\section{Tabel 3 Coefficients ${ }^{a}$}

\begin{tabular}{|ll|r|r|}
\hline Model & \multicolumn{2}{|c|}{ Collinearity Statistics } \\
\hline 1 (Constant) & Tolerance & \multicolumn{1}{c|}{ VIF } \\
\cline { 2 - 3 } & Kepercayaan & & \\
Kemudahan &, 974 & 1,026 \\
Kualitas Informasi &, 697 & 1,434 \\
\end{tabular}

Sumber data dioleh penulis melalui SPSS 22 (2019)

hasil uji Multikolinieritas pada penelitian ini tidak terjadi gejala Multikolinieritas karena semua variabel bebas (independent) memiliki nilai tolerance $>0,1$ dan semua $\mathrm{VIF}<10$

\section{Uji Heteroskedastisitas}

Menurut Priyatno (2017:126) heteroskedastisitas adalah varian residual yang tidak sama pada semua pengamatan di dalam model regresi. Regresi yang baik seharusnya tidak terjadi heteroskedastisitas.

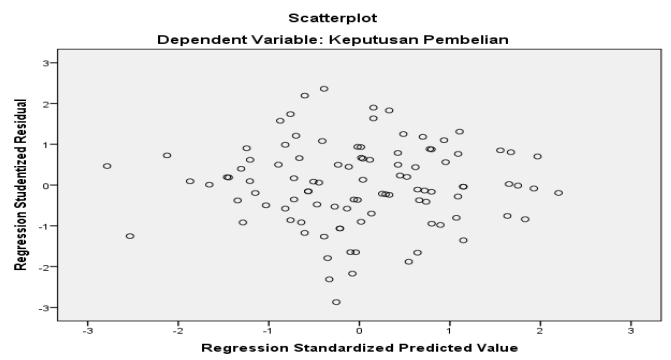

Dengan menggunakan grafik scatterplot menunjukan titik menyebar secara acak dibawah serta diatas angka 0 pada sumbu $\mathrm{Y}$, dan tidak mempunyai pola yang teratur.

\section{Uji Autokorelasi}

Menurut Priyatno (2017:123) uji autokorelasi antara anggota observasi yang disusun menurut waktu dan tempat.Model regresi yang baik seharusnya tidak terjadi autokorelasi.Metode pengujian menggunakan uji Durbin-Watson (DW test).

Tabel 4. Hasil Uji Autokorelasi Model Summary ${ }^{\mathbf{b}}$

\begin{tabular}{|l|r|r|r|r|r|}
\hline Model & $\mathrm{R}$ & R Square & $\begin{array}{c}\text { Adjusted R } \\
\text { Square }\end{array}$ & $\begin{array}{c}\text { Std. Error of } \\
\text { the Estimate }\end{array}$ & $\begin{array}{c}\text { Durbin- } \\
\text { Watson }\end{array}$ \\
\hline 1 &, $363^{\mathrm{a}}$ &, 132 &, 104 & 3,895 & 1,631 \\
\hline
\end{tabular}

Sumber data dioleh penulis melalui SPSS 22 (2019)

$$
\mathrm{DL}<\mathrm{DW}<\mathrm{DU}
$$

Menunjukan bahwa nilai Durbin Watson sebesar 1,631. Dengan jumlah sampel $\mathrm{n}=100$, dan jumlah variabel independent $3(\mathrm{k}=3)$, dengan lavel signifikasi 5\% didapatkan nilai 1,613 
$<1,631<1,736$. Karena nilai Durbin Watson diantara DL dan DU artinya tidak ada kepastian atau kesimpulan yang pasti .

\section{Uji HIPOTESIS}

\section{Analisis Regresi Linear Berganda}

Menurut Priyatno (2017:169) Analisis linier berganda digunakan untuk mengetahui pengaruh atau hubungan secara linier antara dua atau lebih variabel independen dengan satu variabel dependen.

Tabel 5. Hasil uji Regresi Linear Berganda Coefficients ${ }^{\mathrm{a}}$

\begin{tabular}{|c|c|c|c|c|c|c|c|}
\hline \multirow[b]{2}{*}{ Model } & \multicolumn{2}{|c|}{$\begin{array}{c}\text { Unstandardized } \\
\text { Coefficients }\end{array}$} & \multirow{2}{*}{$\begin{array}{c}\text { Standardize } \\
\text { d } \\
\text { Coefficients } \\
\text { Beta }\end{array}$} & \multirow[t]{2}{*}{$\mathrm{t}$} & \multirow[t]{2}{*}{ Sig. } & \multicolumn{2}{|c|}{$\begin{array}{c}\text { Collinearity } \\
\text { Statistics }\end{array}$} \\
\hline & B & Std. Error & & & & Tolerance & VIF \\
\hline $1 \quad$ (Constant) & 41,506 & 5,770 & & 7,193 &, 000 & & \\
\hline Kepercayaan & ,204 & ,085 & ,231 & 2,395 & 019 & ,974 & 1,026 \\
\hline Kemudahan & ,029 &, 150 & ,022 & , 190 &, 850 & ,697 & 1,434 \\
\hline $\begin{array}{l}\text { Kualitas } \\
\text { Informasi }\end{array}$ &,- 290 & , 128 &,- 259 & $-2,269$ &, 026 & 693 & 1,443 \\
\hline
\end{tabular}

Sumber data dioleh penulis melalui SPSS 22 (2019)

Dari hasil menunjukkan hasil Uji Regresi Linear Berganda. Jika dimasukan dalam rumus persamaan regresi perolehan persamaan Regresi sebagai berikut

Keterangan :

$\mathrm{Y}=41,506+0,204 \mathrm{X} 1+0,029 \mathrm{X} 2-0,290 \mathrm{X} 3$

$\mathrm{Y}$

$\mathrm{B} 1, \mathrm{~B} 2, \mathrm{~B} 3=$ Koefisien Regresi masing-masing variabel Independent

$\mathrm{X} 1 \quad=$ Kepercayaan

$\mathrm{X} 2 \quad=$ Kemudahan

X3 $=$ Kualitas Informasi

a

$=$ Konstanta

Hasil analisis dari persamaan Regresi Liniear Berganda tersebut dapat di jelaskan sebagai berikut :

a. Nilai Konstanta $=41,506$. jika ini dapat diartikan jika Kepercayaan (X1), Kemudahan(X2), dan Kualitas Informasi(X3) nilainya 0, maka Keputusan Pembelian(Y) bernilai sebesar 41,506.

b. Koefisien Regresi Kepercayaan (X1) bernilai positif sebesar 0,204, artinya jika variabel Kepercayaan meningkat 1 maka Keputusan Pemebelian meningkat 0,204 dengan asumsi variabel independen lain nilainya tetap.

c. Koefisien Regresi Kemudahaan (X2) bernilai positif sebesar 0,029 artinya jika variabel Indepeinden lain bernilai tetap dan Variabel Kemudahan kenaikan 1, maka Keputusan Pemebelian (Y) mengalamin peningkatan sebesar 0,029 dan sebaliknya dengan asumsi variabel independen lain nilainya tetap.

d. Koefisien Regresi Kualitas Informasi (X3) bernilai Negatif -0,290. Artinya jika Variabel independen lain bernilai tetap dan Kualitas Informasi (X3) Mengalami kenaiakan 1, Maka Keputusan pembelian mengalami penurunan -0,290 dan sebaliknya dengan asumsi variabel independen lain nilainya tetap. 


\section{Uji F (Uji Simultan)}

Uji $F$ digunakan untuk menguji ada atau tidaknya pengaruh variabel - variabel independen terhadap variabel dependen secara simultan (bersama - sama), dengan kriteria pengujian sebagai berikut:

a. Jika Fhitung $>$ Ftabel maka Ho ditolak dan Ha diterima.

b. Jika Fhitung < Ftabel maka Ho diterima dan Ha ditolak

Tabel 6. Hasil uji simultan ANOVA $^{\mathrm{a}}$

\begin{tabular}{|ll|r|r|r|r|c|}
\hline \multicolumn{2}{|l|}{ Model } & $\begin{array}{c}\text { Sum of } \\
\text { Squares }\end{array}$ & df & $\begin{array}{c}\text { Mean } \\
\text { Square }\end{array}$ & F & Sig. \\
\hline 1 & Regression & 220,527 & 3 & 73,509 & 4,846 &, $003^{\mathrm{b}}$ \\
& Residual & 1456,113 & 96 & 15,168 & & \\
& Total & 1676,640 & 99 & & & \\
\hline
\end{tabular}

Sumber data dioleh penulis melalui SPSS 22 (2019)

Hasil uji $\mathrm{f}$ dengan nilai sebesar 4,846 $>2,699$ (f hitung $>\mathrm{f}$ tabel dan nilai signifikasi sebesar 0,003 $<0,05$ maka Ho ditolak. Yang artinya Variabel independent (Kepercayaan, Kemudahan, Kualitas Informasi) secara simultan berpengaruh positif dan signifikan terhadap variabel dependent (keputusan pembelian).

\section{Uji t(uji parsial)}

Uji statistik t atau uji parsial digunakan untuk mengetahui apakah model regresi variabel Kepercayaan, Kemudahan, dan Kualitas Informasi secara parsial (sendiri - sendiri) berpengaruh signifikan terhadap variabel dependen yaitu keputusan pembelian jika kolom sig $<$ dari 0,05 dan thitung $>$ t tabel maka H0 ditolak dan Ha diterima.

Tabel 7. Hasil Uji Parsial

Coefficients $^{\mathrm{a}}$

\begin{tabular}{|l|r|r|r|r|r|r|r|}
\hline \multirow{2}{*}{ Model } & \multicolumn{2}{c|}{$\begin{array}{c}\text { Unstandardized } \\
\text { Coefficients }\end{array}$} & $\begin{array}{c}\text { Standardized } \\
\text { Coefficients }\end{array}$ & $\mathrm{t}$ & \multicolumn{2}{|c|}{ Sig. } & \multicolumn{2}{|c|}{$\begin{array}{c}\text { Collinearity } \\
\text { Statistics }\end{array}$} \\
\cline { 2 - 8 } & \multicolumn{1}{c|}{$\mathrm{B}$} & \multicolumn{1}{c|}{$\begin{array}{c}\text { Std. } \\
\text { Error }\end{array}$} & Beta & & & $\begin{array}{c}\text { Tolera } \\
\text { nce }\end{array}$ & VIF \\
\hline 1(Constant) & 41,506 & 5,770 & & 7,193 &, 000 & & \\
Kepercayaan &, 204 &, 085 &, 231 & 2,395 &, 019 &, 974 & 1,026 \\
Kemudahan &, 029 &, 150 &, 022 &, 190 &, 850 &, 697 & 1,434 \\
Kualitas &,- 290 &, 128 &,- 259 & $-2,269$ &, 026 &, 693 & 1,443 \\
Informasi & & & & & &
\end{tabular}

Sumber data dioleh penulis melalui SPSS 22 (2019

1) Hasil statistik uji $t$ untuk variabel Kepercayaan diperoleh nilai t hitung sebesar 2,395 dengan nilai signifikansi sebesar $0,019(0,019<0,05)$ dan koefisien regresi mempunyai nilai positif sebesar 0,204 ; maka hipotesis yang menyatakan bahwa "Terdapat pengaruh positif Kepercayaan terhadap keputusan pembelian online di Shopee"

2) Hasil statistik uji t untuk variabel Kemudahan diperoleh nilai t hitung sebesar 0,190 dengan nilai signifikansi sebesar $0,850(0,850>0,05)$ dan koefisien regresi mempunyai nilai positif sebesar 0,029 ; maka hipotesis yang menyatakan bahwa "Kemudahan Tidak berpengaruh positif terhadap keputusan pembelian online di Shopee."

3) Hasil statistik uji t untuk variabel Kualitas Informasi diperoleh nilai t hitung sebesar -2,269 dengan nilai signifikansi sebesar 0,026 $(0,026<0,05)$ dan koefisien regresi mempunyai nilai negatif sebesar- 0,290 ; maka hipotesis yang menyatakan 
bahwa "Terdapat pengaruh negatif Kualitas Informasi terhadap keputusan pembelian online di Shopee."

\section{Koefisien Determinasi (R2)}

Koefisensi Determinasi (R2) bertujuan untuk mengukur seberapa jauh kemampuan model dalam menerangkan variasi variabel dependen. Nilai koefisiensi determinasi adalah antara nol dan satu

\begin{tabular}{|l|r|r|r|r|c|}
\hline \multicolumn{7}{|l|}{.Tabel 8. Hasil uji Koefisien Determinasi Model Summary } \\
\hline $\begin{array}{l}\text { Mode } \\
1\end{array}$ & $\mathrm{R}$ & R Square & $\begin{array}{c}\text { Adjusted R } \\
\text { Square }\end{array}$ & $\begin{array}{c}\text { Std. Error of } \\
\text { the Estimate }\end{array}$ & $\begin{array}{c}\text { Durbin- } \\
\text { Watson }\end{array}$ \\
\hline 1 &, $363^{\mathrm{a}}$ &, 132 &, 104 & 3,895 & 1,631 \\
\hline
\end{tabular}

Sumber data dioleh penulis melalui SPSS 22 (2019)

Dapat diketahui bahwa koefisien determinasi ( Adjusted R Square) yang diperoleh sebesar 0,104 atau $10,4 \%$ Sisanya yaitu $89,6 \%$ keputusan pembelian dipengaruhi oleh variabel variabel yang tidak diteliti dalam penelitian seperti Presepsi Harga, Presepsi Manfaat ,Resiko, Keamanan dan lain sebagainya .

\section{Pembahasan}

\section{Pengaruh Kepercayaan terhadap Keputusan Pembelian secara online di aplikasi Shopee}

Variabel kepercayaan memiliki 3 dimensi kepercayaan yaitu Kompetensi Perusahaan, Integritas,dan Kesungguhan. Hasilnya dari ketiga dimensi tersebut menurut penilaian responden bahwa dalam melakukan keputusan pembelian di aplikasi online Shopee responden percaya oleh Kesungguhan Shopee dalam menyediakan produk produk relative dipercaya, kesungguhan dalam menampilkan biaya. Hal ini di tunjukkan dengan skor dimensi paling tinggi sebesar 3,79 di antara dimensi yang lain seperti Kompetensi Perusahaan dengan nilai 3,76, dan Integritas dengan nilai 3,78. Dan yang menjadi ukuran paling tinggi dari dimensi kesungguhan adalah pada indikator dimana shopee telah menampilkan kesungguhannya dengan nilai 3,92 dalam menampilkan biaya yang sesungguhnya dan yang terendah dengan nilai 3,63 adalah maximal dalam hal pelayanan konsumen. Namun secara umum pelayanan serta keunggulan keunggulan yang ditawarkan aplikasi Shopee telah mampu meningkatkan Kepercayaan konsumen sehingga responden tersebut dapat terdorong munculnya Keputusan Pembelian secara online di aplikasi Shopee.

\section{Pengaruh Kemudahan terhadap Keputusan Pembelian secara online di aplikasi Shopee}

Variabel Kemudahan memiliki 3 dimensi Kemudahan yaitu mudah dipelajari, mudah digunakan, mudah menjadi mahir. Dan hasilnya dari ketiga dimensi tersebut menurut penilaian responden bahwa dalam melakukan Keputusan Pembelian di aplikasi online Shopee responden percaya bahwa shopee telah memberikan Kemudahan konsumen yaitu, Mudah dipelajari . Hal ini di tunjukkan dengan skor dimensi paling tinggi sebesar 4,05 di banding dimensi lain yaitu mudah digunakan dengan nilai 3,97 dan menjadi mahir dengan nilai 3,95. Dan yang menjadi ukuran Kemudahan paling tinggi dari dimensi mudah dipelajari adalah pada indikator dimana aplikasi Shopee yang mudah dipelajari dengan nilai 4,13 dan yang terendah dengan nilai 3,97 adalah mudah mendapatkan aplikasi. Dalam variable Kemudahan, indikator yang terendah terendah adalah mudah dan praktis digunakan dengan nilai 3,94 yang terdapat pada dimensi mudah digunakan.Namun secara umum Kemudahan serta keunggulan yang diberikan Shopee telah mampu membuat responden merasa dimudahkan sehingga 
konsumen pun merasa jika sebuah Kemudahan tersebut tidak dapat mempengaruhi Keputusan Pembelian responden di aplikasi Shopee.

\section{Pengaruh Kualitas Informasi terhadap Keputusan Pembelian secara online di aplikasi Shopee}

Variabel Kualitas Informasi memiliki 3 dimensi yaitu waktu informasi, konten informasi, bentuk informasi. Dan hasilnya dari ketiga dimensi tersebut menurut penilaian responden bahwa dalam melakukan Keputusan Pembelian di aplikasi online Shopee responden percaya bahwa shopee telah memberikan Kualitas Informasi yaitu, bentuk informasi. Hal ini di tunjukkan dengan skor dimensi bentuk informasi paling tinggi sebesar 4,03 di banding dimensi lain yaitu waktu informasi dengan nilai 3,91 dan konten informasi dengan nilai 3,81, Dan yang menjadi ukuran Kualitas informasi paling tinggi dari dimensi bentuk informasi adalah pada indikator dimana informasi bentuk gambar dengan nilai 4,05 dan yang terendah dengan nilai 4,02 adalah informasi simulasi.Dalam variable Kualitas Informasi, indikator yang terendah terendah adalah ketepatan Informasi dengan nilai 3,66 yang terdapat pada dimensi konten informasi.Namun secara umum Kualitas Informasi serta keunggulan keunggulan yang diberikan Shopee telah mampu membuat konsumen merasakan manfaat akan Kualitas Informasi tersebut,akan tetapi responden merasa nilai manfaat yang sampai masih kurang sehingga responden pun merasa jika Kualitas Informasi tersebut tidak dapat mempengaruhi Keputusan Pembelian responden di aplikasi Shopee

\section{Kesimpulan}

1. Variabel Kepercayaan(X1), Kemudahan(X2) dan Kualitas Informasi(X3) secara online di Shopee secara simultan berpengaruh secara signifikan terhadap keputusan pembelian di Shopee(Y).

2. Variabel Kepercayaan (X1) di Shopee berpengaruh positif terhadap terhadap keputusan pembelian (Y) di Shopee secara parsial.

3. Variabel Kemudahan (X2) di Shopee tidak berpengaruh positif terhadap variabel Keputusan Pembelian (Y) di Shopee secara parsial.

4. Variabel Kualitas Informasi di Shopee berpengaruh negatif terhadap variabel Keputusan Pembelian (Y)di Shopee secara parsial.

\section{Saran}

a. Kepercayaan, Kemudahan, dan Kualitas Informasi terhadap Keputusan Pembelian perlu di tingkatkan kembali karna melihat hasil dari penelitian ini, sebaiknya Shopee lebih meningkatkan terkait Kemudahan Penggunaan dan Kualitas Informasi. Dan faktor lain yang dapat mempengaruhi Keputusan Pembelian.

b. Hasil penelitian menyatakan Kepercayaan yang berpengaruh dengan Keputusan Pembelian, Sebaiknya Shopee mempertahankan dimensi kesungguhannya dalam menampilkan biaya sesungguhnya, dan yang juga Shopee patut meningkatkan dimensi kompetensi perusahaan atas kualitas produknya kepada konsumen sehingga konsumen semakin yakin akan pengambilan Keputusan Pembelian di Shopee.

c. Hasil penelitian menyatakan Kemudahan tidak berpengaruh terhadap Keputusan Pembelian, sebaiknya Shopee mempertahankan dimensi mudah dipelajari dan tidak ada kesulitan penggunaan. Shopee perlu meningkatkan dimensi mudah digunakan serta mudah dan praktis penggunaannya agar para kosumen merasa nyaman menggunakan hingga konsumen semakin yakin akan pengambilan Keputusan Pembelian di Shopee.

d. Hasil penelitian menyatakan Kualitas Informasi yang berpengaruh negatif terhadap Keputusan Pembelian, Shopee haruslah mempertahankan dimensi bentuk informasi dalam bentuk gambar di rasakan konsumen saat menggunakan Shopee bisa menarik bagi para 
konsumen. Shopee harus meningkatkan dimensi konten informasi dalam keakuratan sebuah informasi yang ditampilakan kepada konsumen agar konsumen semakin yakin akan pengambilan Keputusan Pembelian di Shopee.

\section{DAFTAR PUSTAKA}

\section{Sumber Buku :}

Erna, Ferrina Dewi. (2008). Merek \& psikologi konsumen. Edisi : pertama. Yogyakarta: Graha Ilmu.

Jogiyanto. 2007. Sistem Informasi Keprilakuan. Penerbit ANDI. Yogyakarta.

Kotler dan Keller, 2012. Manajemen Pemasaran, Edisi 13, Jilid 1, Jakarta: PT.Indeks.

O'Brien, dan Marakas. (2014). Sistem Informasi Manajemen.Jakarta :Salemba Empat.

Philip Kotler, and Gary Amstrong. (2016). Prinsip-prinsip Pemasaran. Edii13. Jilid 1. Jakarta:Erlangga.

Priyatno, Duwi. (2017). Panduan praktis olah data menggunakan SPSS. Yoyakarta: Penerbit Andi

Sugiyono. 2017. Metode Penelitian Kuantitatif, Kualitatif Dan R\&D. Bandung: Alfabeta.

Sumber Jurnal:

Desy, W.,\& Apriatni, E, P. (2018). Pengaruh Kemudahan, Kualitas Informasi, Dan Kepercayaan Terhadap Keputusan Pembelian Secara Online Pada Situs Lazada.

Erry, S.P., \& Eko,W. (2019), "Analisis Kepercayaan dan Kemudahan terhadap Keputusan Pembelian secara Online", Jurnal Insitusi Politeknik Ganesha Medan Juripol, Volume 2 Nomor 1 Februari 2019P-ISSN : 2599-1779 E-ISSN : 2599-1787

Kartika, A., \& Hendra, G. (2018). Pengaruh Kepercayaan, Kemudahan Dan Kualitas Informasi Terhadap Keputusan Pembelian Daring Di Aplikasi Bukalapak Pada Mahasiswa Politeknik Negeri Batam. Jurnal of Applied Administration vol.2 no.1 2018 e-ISSN: 2548-9909

Maria, C, P., \& Helen, W. (2015). Analisa Pengaruh Kepercayaan, Kemudahan, Kualitas Informasi, Dan Tampilan Produk Terhadap Keputusan Pembelian Melalui Pemasaran Di Media Sosial. Studi pada penguna media sosial di shapeharve.

Maya,Puspa,S.(2015). Pengaruh Kepercayaan, Kemudahan, Dan Kualitas Informasi Terhadap Keputusan Pembelian Secara Online Di Situs Lazada.Co.Id Pada Mahasiswa/I Fakultas Ekonomi Dan Bisnis Usu.

McKnight et al. (2002), "Developing and Validating Trust Measures for e-Commerce: An Integrative Typology", , Information Systems Research, No. 3, Vol. 13, 334-359

Muslichah, E., Erma,W., Henky,S.,\& Sri ,H. (2012). Penggunaan Teknologi Internet Dalam Sistem Penjualan Online Untuk Meningkatkan Kepuasan Dan Pembelian Berulang Produk Batik Pada Usaha Kecil Dan Menengah Di Jawa Timur.

Noorlianah, R . (2018). Jurnal Presepsi Mahasiswa Terhadap Online Shop .

Nuri,Apriyani \& Suharti .(2016) "Analisis Pengaruh Presepsi Kemanfaatan, Presepsi Kemudahan Dan Kepercayaan Terhadap Minat Beli Ulang Penggunaan Smartphone Xiaomi".

Nurmadina., (2016). Analisis Faktor-Faktor Yang Mempengaruhi Keputusan Pembelian Secara Online (Studi Kasus Pada Konsumen fashion Online Di Kota Makassar)

Rachmahita, Resti. H. (2018). Pengaruh Kepercayaan, Kemudahan, Dan Keamanan Terhadap Keputusan Pembelian Pada Situs E-Marketplace.

Riski, A. (2015). "Pengaruh Kepercayaan, Kemudahan, Kualitas Informasi Dan Persepsi Resiko Terhadap Keputusan Pembelian Melalui Situs Jejaring Sosial Di Semarang"

Sakina, M. (2017) Pengaruh Persepsi Manfaat, Kemudahan Penggunaan, Dan Kesesuaian Terhadap Keputusan Menggunakan Mobile Banking Bank Mandiri Di Surabaya .

Septi, Maulidiyahwati. (2017) "Pengaruh Kepercayaan, keamanan, kualitas pelayanan dan presepsi resiko menggunakan e-commerce terhadap keputusan pembelian online”.

Sherren., Hartiwi P.(2012). "Analisis Pengaruh Kepuasan Pelanggan Terhadap Kepercayaan Pelanggan dan Dampaknya Pada Retensi Pelanggan JNE Pangkalpinang” 
Winda., S.,(2018). "pengaruh citra merek, kualitas pelayanan dan harga terhadap keputusan pembelian hush puppies di central departemen store grand indonesia Jakarta".

\section{Sumber website:}

Dani Wijaya . (2017)., Tutupnya beberapa gerai konvensional karena pembeli beralih ke toko "online", Www. Kompasiana.Com/ Daniwijaya/ 5a012fb0c226f97388003462/ , 23 maret 2019.

Andi D. R. (2019)., Hootsuite (we are social): Indonesian Digital Report 2019., https://andi.link/hootsuite-we-are-social-indonesisn-digital-report-2019/ , 23 maret 2019

Iprice insight .(2019)., Daftar 50 website \&aplikasi e-commerce di indonesia 2018., https://iprice.co.id/insights/mapofecommerce/ ,3 April 2019

Logopedia. (2015)., Shopee Logopedia Fandom Powerd.,https:// logos.fandom.com / wiki/Shopee, 10 Mei 2019 